\title{
Thrombocytosis as an Initial Presentation of Plasma Cell Neoplasm: A Case Report
}

\author{
Arslan Naeem ${ }^{1}$, Surabhi Amar ${ }^{2}$, Divyesh Mehta ${ }^{2}$, Mustafa N. Malik ${ }^{3}$
}

1. Internal Medicine, Maricopa Medical Center, Phoenix, USA 2. Hematology and Oncology, Maricopa Medical Center, Phoenix, USA 3. Internal Medicine, The University of Arizona, Tucson, USA

Corresponding author: Mustafa N. Malik, mustafa.nadeem.malik@gmail.com

\begin{abstract}
Plasma cell neoplasms are usually associated with normal or decreased platelet count. The association of thrombocytosis and multiple myeloma is exceedingly rare, with only six such cases reported in the literature until now. Differentiating clonal from secondary causes of thrombocytosis can be extremely difficult, yet the distinction has important therapeutic implications. We report the case of a woman presenting with thrombocytosis that led to the diagnosis of multiple myeloma. The possible etiological link between both these entities is also discussed.
\end{abstract}

Categories: Internal Medicine, Oncology

Keywords: thrombocytosis, plasma cell neoplasm, multiple myeloma, myeloproliferative disorders, essential thrombocythemia

\section{Introduction}

Thrombocytosis can be reactive (more common) or a primary myeloproliferative disorder (MPD) which includes essential thrombocythemia. Many inflammatory (celiac disease, inflammatory bowel disease, pancreatitis, iron deficiency), rheumatologic (vasculitis), infectious, or neoplastic conditions cause reactive thrombocytosis. It has been reported with many solid tumors (e.g., lung, stomach, ovarian and renal cancers) as well [1]. Patients with secondary thrombocytosis typically have clinically apparent, coexisting, underlying systemic diseases that account for the elevated platelet count. Unlike patients with secondary thrombocytosis, those with clonal thrombocytosis have thrombotic, vascular, and bleeding complications. Hematological malignancies are usually associated with thrombocytopenia. The association between multiple myeloma and thrombocytosis is infrequent. As far as thrombocytosis is concerned, the appearance of multiple myeloma has been reported in only six instances [2]. We report the case of a woman who had multiple myeloma with associated thrombocytosis. We also reviewed the published data on this association.

Received 02/07/2019 Review began 02/27/2019 Review ended 03/14/2019 Published 03/21/2019

๑) Copyright 2019

Naeem et al. This is an open access article distributed under the terms of the Creative Commons Attribution License CC-BY 3.0., which permits unrestricted use, distribution, and reproduction in any medium, provided the original author and source are credited.

\section{Case Presentation}

A 32-year-old female presented with complaints of fatigue and tingling sensation in extremities. Physical exam was unremarkable without evidence of lymphadenopathy or hepatosplenomegaly. Laboratory findings were significant for hemoglobin (Hb) at $17.2 \mathrm{~g} / \mathrm{dL}$, white blood cell (WBC) count at $9 \times 103 / \mu \mathrm{L}$, and platelets $594 x 103 / \mu \mathrm{L}$. She had no fever, weight loss, joint pains or other systemic symptoms. Work up for thrombocytosis was initiated. Bone marrow biopsy showed mildly hypo-cellular marrow (40\%) with normal trilineage hematopoiesis, no evidence of malignancy. Janus kinase 2 (JAK2) exon 12 mutation was negative. One month later, she presented to the emergency department (ER) with left-hand weakness and numbness. Computed tomography (CT) scan showed bilateral cervical chain lymphadenopathy and $6 \times 4.5 \mathrm{~cm}$ soft tissue mass in the paraspinal muscle of the thoracic inlet invading the T1 and posterior rib with pathologic compression fracture (Figure 1).
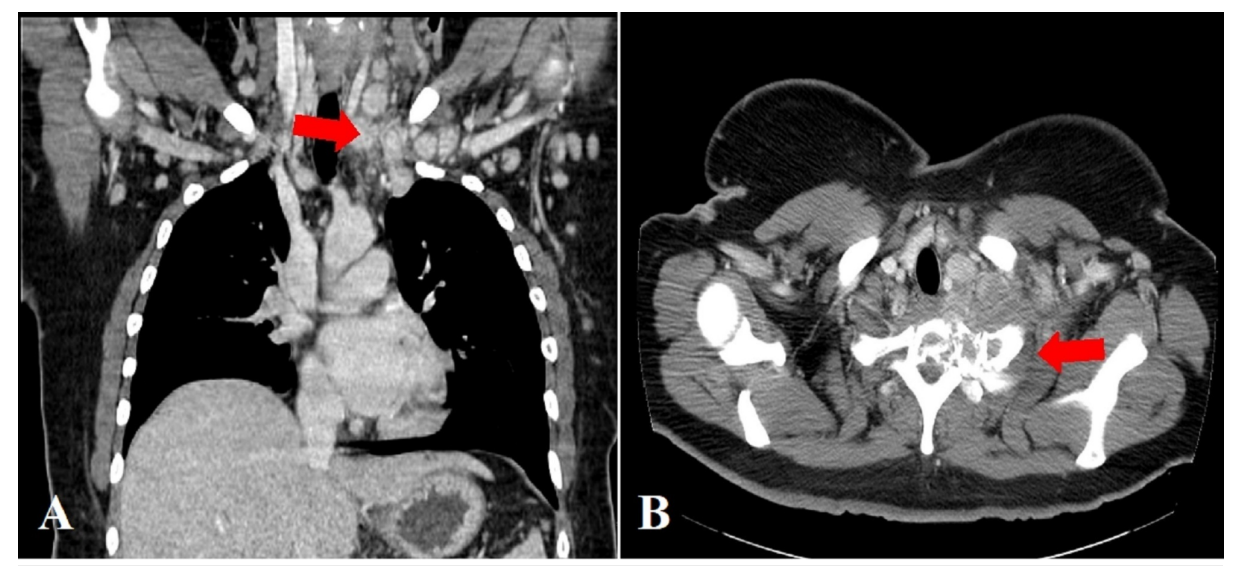


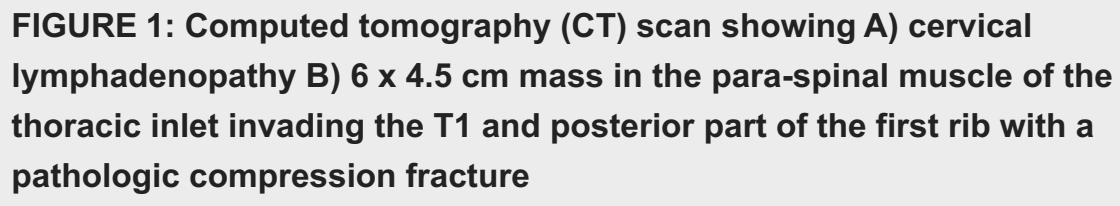

Open biopsy with cervical thoracic fixation from C4-T5 was done. Pathology showed neoplastic infiltration by lambda restricted monoclonal plasma cells. Flow cytometry of the tumor showed 3\% lambda restricted plasma cells (Figure 2).
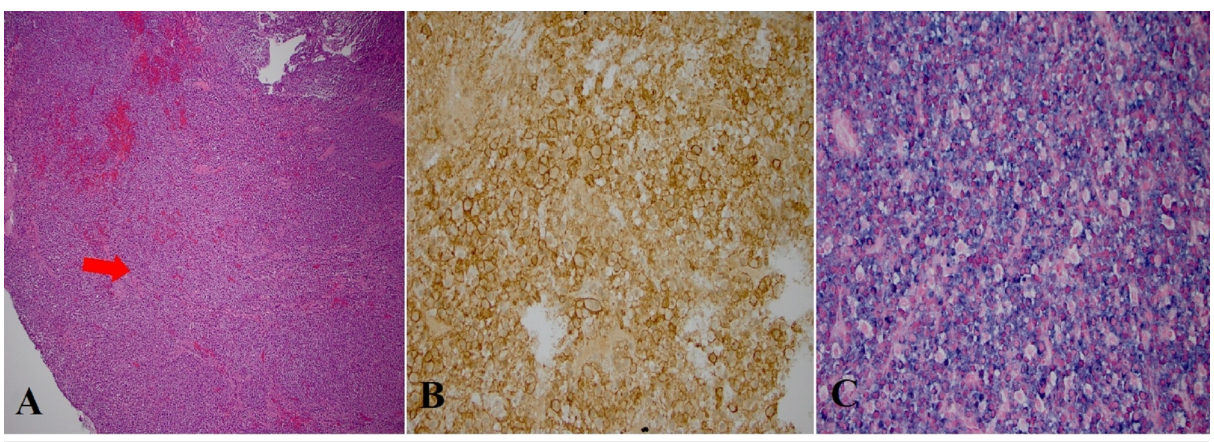

FIGURE 2: Tissue staining from the open biopsy of the paraspinal mass

A) hematoxylin eosinophilin stain showing tumor infiltration B) CD 138 positive immunochemical staining for plasma cells $\mathrm{C}$ ) staining for lambda restricted plasma cells.

A complete skeletal survey was negative for lytic lesions. Serum protein electrophoresis showed immunoglobulin (Ig) G lambda restricted M spike of $0.2 \mathrm{~g} / \mathrm{dL}$. Lactate dehydrogenase (LDH) was normal. Beta-microglobulin level was $2.7 \mathrm{mg} / \mathrm{L}$. Positron emission tomography (PET) scan showed lytic lesions in her iliac bones and sacrum. A diagnosis of multiple myeloma was made and Revlimid/Velcade/Dexamethasone (RVD) regimen was given. Following treatment, her platelet count became normal at $275 \times 103 / \mu \mathrm{L}$. She had a repeat bone marrow biopsy and it was again normal with negative calreticulin (CALR) gene mutation, negative fluorescence in situ hybridization (FISH) for myeloma and MPDs and normal cytogenetics. JAK 2 mutation analysis was positive. The patient does not have any primary bone marrow fibrosis. She went on to have an autologous stem cell transplant and is currently on maintenance Revlimid therapy.

\section{Discussion}

Thrombocytosis is typically discovered as an incidental laboratory finding during routine workup. However, when found, it creates an important diagnostic challenge. In a study involving 280 hospitalized patients with platelet counts of one million per cubic millimeter or higher, $82 \%$ (231 patients) had secondary thrombocytosis, $14 \%$ (38 patients) had an MPD while only $4 \%$ (11 patients) had thrombocytosis of uncertain cause [3]. In another study including 732 patients with platelet counts of 500,000 per cubic millimeter or higher, $88 \%$ (643 patients) had secondary thrombocytosis; the most frequent underlying causes in these patients were tissue damage during major surgery, chronic inflammation, infection and carcinoma [4].

Thrombocytosis can be a paraneoplastic manifestation of malignancy. Myeloma has been reported in cases of MPDs causing thrombocytosis. POEMS syndrome (polyneuropathy, organomegaly, endocrinopathy, monoclonal protein, and skin changes) can be associated with thrombocytosis. In the absence of underlying MPD or POEMS syndrome, myeloma is usually associated with normal or low platelet counts [5-6]. It has been suggested that the cytokine interleukin-6 (IL-6), an important component in the pathogenesis and progression of multiple myeloma may provide a common link between multiple myeloma and thrombocytosis. IL-6 is a potent human myeloma-cell growth factor as well as a promoter of megakaryocytopoiesis [7-8]. However, the exact mechanism still remains unclear; other pathogenetic mechanisms need to be explored. The association of multiple myeloma, a lymphoproliferative neoplasm, with thrombocytosis, though documented, is extremely rare [9]. To date, only six cases of myeloma associated with thrombocytosis have been reported [5-6,10] (Table 1). 


\section{Cureus}

\begin{tabular}{|c|c|c|c|c|c|c|}
\hline Patient & Sex & Bone Marrow Biopsy & $\begin{array}{l}\text { Protein } \\
\text { (g/100ml) }\end{array}$ & $\begin{array}{l}\text { Type of M component in } \\
\text { serum }\end{array}$ & $\begin{array}{l}\text { Platelet Count } \\
(/ \mu L)\end{array}$ & Ref. \\
\hline 1 & Male & $60 \%$ plasma cells & Elevated & N.R & 800,000 & [6] \\
\hline 6 & Male & $\begin{array}{l}6 \% \text { plasma cells with otherwise normal } \\
\text { marrow }\end{array}$ & 4.99 & IgG-Gamma & $400-780,000$ & [6] \\
\hline 3 & Male & $90 \%$ plasma cells & 6.2 & N.R & $400-8 / 1,000$ & [6] \\
\hline 4 & Male & $65 \%-10 \%$ plasma cells & Elevated & $\lg D$ & $931-984,000$ & [5] \\
\hline 5 & Male & $10 \%$ plasma cells & 2.25 & IgA-Kappa & $980-1420,000$ & [10] \\
\hline 6 & Female & $30 \%-40 \%$ plasma cells & N.R & lgG-Kappa & 1220,000 & [10] \\
\hline
\end{tabular}

TABLE 1: Report of cases of multiple myeloma associated with thrombocytosis

g: gram; Ig: immunoglobulin; ml: milliliter; $\mu$ L: microliter; N.R: not reported; Ref: references.

The challenge of correctly identifying the etiology of thrombocytosis in a patient becomes crucial when the clinician has to decide treatment options. It is critical to identify the etiology of thrombocytosis even when it is clinically inapparent so that treatment can be directed to the underlying disorder [1]. Work up for thrombocytosis should exclude autoimmune disorders, chronic inflammatory disorders, infections, and iron deficiency. In the absence of MPD, underlying malignancy should always be ruled out in patients found to have unexplained thrombocytosis. Although not yet clinically applicable, development of clonality assays and tests for c-Mpl expression in megakaryocytes and platelets promises to provide diagnostic tools to differentiate clonal from secondary causes of thrombocytosis $[1,11]$.

\section{Conclusions}

Patients with multiple myeloma usually present with thrombocytopenia. However, thrombocytosis can be an initial presentation. Before ascribing thrombocytosis to a clonal cause (myeloproliferative disorder), which is a diagnosis of exclusion and has different therapeutic implications, secondary causes of thrombocytosis must be ruled out.

\section{Additional Information}

\section{Disclosures}

Human subjects: Consent was obtained by all participants in this study. Conflicts of interest: In compliance with the ICMJE uniform disclosure form, all authors declare the following: Payment/services info: All authors have declared that no financial support was received from any organization for the submitted work. Financial relationships: All authors have declared that they have no financial relationships at present or within the previous three years with any organizations that might have an interest in the submitted work. Other relationships: All authors have declared that there are no other relationships or activities that could appear to have influenced the submitted work.

\section{Acknowledgements}

Authors would like to acknowledge Dr. Iman Feiz-Erfan for reviewing the manuscript.

\section{References}

1. Schafer AI: Thrombocytosis. N Engl J Med. 2004, 350:1211-1219. 10.1056/NEJMra035363

2. Huang J, Luo X, Zhu Y, Wang L, Liu L: Coexistence of multiple myeloma with essential thrombocythemia: a case report and literatures review [Article in Chinese]. Zhonghua Xue Ye Xue Za Zhi. 2014, 35:757-759.

3. Buss DH, Cashell AW, O'Connor ML, Richards II F, Case LD: Occurence, etiology, and clinical significance of extreme thrombocytosis: a study of 280 cases. Am J Med. 1994, 96:247-253.

4. Griesshammer M, Bangerter M, Sauer T, Wennauer R, Bergmann L, Heimpel H: Aetiology and clinical significance of thrombocytosis: analysis of 732 patients with an elevated platelet count. J Intern Med. 1999, 245:295-300.

5. Nestler JE: Immunoglobulin D multiple myeloma with thrombocytosis . Ann Intern Med. 1981, 94:412-412. 10.7326/0003-4819-94-3-412_1

6. Zimelman AP: Thrombocytosis in multiple myeloma . Ann Intern Med. 1973, 78:970-971. 10.7326/00034819-78-6-970

7. Gadó K, Domján G, Hegyesi H, Falus A: Role of INTERLEUKIN-6 in the pathogenesis of multiple myeloma . Cell Biol Int. 2000, 24:195-209. 10.1006/cbir.2000.0497 


\section{Cureus}

8. Kaser A, Brandacher G, Steurer W, et al.: Interleukin-6 stimulates thrombopoiesis through thrombopoietin: role in inflammatory thrombocytosis. Blood. 2001, 98:2720-2725.

9. Majhail NS, Lichtin AE: Rare coexistence of multiple myeloma with essential thrombocythemia: report of two cases. Haematologica. 2003, 88:Ecr09.

10. Selroos O, Van Assendelft A: Thrombocythaemia and multiple myeloma: a report on two cases . Acta Med Scand. 1977, 201:243-247. 10.1111/j.0954-6820.1977.tb15692.x

11. Liu E, Jelinek J, Pastore YD, Guan Y, Prchal JF, Prchal JT: Discrimination of polycythemias and thrombocytoses by novel, simple, accurate clonality assays and comparison with PRV-1 expression and BFUE response to erythropoietin. Blood. 2003, 101:3294-3301. 10.1182/blood-2002-07-2287 